\title{
JAMUR ENDOSIOMBION SI BINTANG LAUT (Asterias forbesi ) SEBAGAI ALTERNATIF ANTIBAKTERI BARU PADA BAKTERI PENYEBAB INFEKSI SALURAN PENCERNAAN
}

\author{
Rusli, Muh Danial Fajri, A. Sri Nila Sari, Nur Asmasari \\ Fakultas Farmasi Universitas Muslim Indonesia, Makassar \\ Email : rusli@umi.ac.id
}

\begin{abstract}
Search of new antibacterial compounds, continuously carried out in line with the increasing number of new diseases emerging, ranging from infectious diseases, cancer and other dangerous diseases. Bioactive compounds can be obtained from several sources, including from plants, animals, microbes and marine organisms, one of which is a starfish, including the endosymbiont. The research of activity fungal isolates endosymbiont on the starfish Asterias forbesi types have been carried out in order to get a fungal isolates that have activity eradicate pathogenic bacteria, especially in the gastrointestinal tract. This research method is isolation of fungal endosymbionts on the sample starfish with Potato Dextrose Agar Chloramfenikol (PDAC) medium at room temperature for $3 \times 24$ hours. Endosymbiont fungal isolates was purified by the quadrant method, until pure fungal isolates obtained, then do the fermentation with Yeast Maltose Broth (MYB) medium on shaker at a speed of 200 rpm for $14 \times 24$ hours. The Results of fermentat continued antibacterial activity using agar diffusion method. The Results isolation of fungal endosymbiont on Starfish Asterias forbesi types obtained five (5) pure fungal isolates endosymbiont. From the results of fermentation obtained test results that indicate the antibacterial activity of fungal isolates endosymbiont on Starfish (Asterias forbesi) provide activity against Pseudomonas aeruginosa, Eschericia coli, Salmonella thypi, Shigella dysentriae, Staphylococcus auerus, and Vibrio cholerea bacterial. The conclusions in this study was isolate fungal endosymbionts IJBL FF-UMI 04 the most active inhibits all the bacterial test. Isolates with the greatest inhibit zone is isolate IJBL FF-UMI 03 on the test bacteria Salmonella thypi of $21.3 \mathrm{~mm}$.
\end{abstract}

Keywords : Fungal endosymbionts, starfish (Asterias forbesi), antibacterial, gastrointestinal infections.

\section{PENDAHULUAN}

Penyakit infeksi terutama di negara tropis seperti Indonesia masih merupakan permasahan yang menuntut perhatian besar, bahkan pada tahun 2006, dilaporkan merupakan penyakit kematian terbesar di dunia. Insidensi infeksi apapun meningkat atau menurun seiring dengan perubahan imunitas penderita dan akibat perubahan virulensi patogen. Untuk mengatasi penyakit ini, 
Jamur endosiombion si bintang laut (Asterias forbesi) sebagai alternatif antibakteri baru pada bakteri penyebab infeksi saluran pencernaan

penggunaan antimikroba atau antiinfeksi masih merupakan pilihan utama. ${ }^{1,2}$

Dalam pengobatan penyakit infeksi karena mikroba, antibiotika mempunyai peranan penting, dimana antibiotika diharapkan mampu mengeliminasi mikroba penyebab infeksi. Akan tetapi kebanyakan obat antibiotika menyebabkan resisten terhadap mikroba. Sehingga untuk menghindari masalah ini, para ilmuan lebih tertarik untuk mengembangkan antibiotik baru dari organisme uniseluler, jamur, alga, dan tumbuhan tingkat tinggi. ${ }^{3}$

Indonesia memiliki sumberdaya alam laut yang besar baik ditinjau dari kuantitas maupun keanekaragaman hasilnya. Meskipun organisme laut merupakan sumber senyawa obat yang berpotensi besar, sedikit sekali obat dari bahan alam yang berasal dari laut. Kebanyakan obat Kita justru berasal dari tanaman atau mikroorganisme darat. Senyawa obat yang terdapat di dalam organisme laut memiliki struktur kimia beraneka ragam. Struktur molekulnya pun tidak sama dengan yang ditemukan pada tanaman darat.

Pencarian sumber senyawa bioaktif terus menerus dilakukan seiring dengan makin banyaknya

penyakit-penyakit baru yang bermunculan, mulai dari penyakit infeksi, kanker dan beberapa penyakit berbahaya lainnya. senyawa bioaktif dapat diperoleh dari beberapa sumber, diantaranya dari tumbuhan, hewan, mikroba dan organisme laut. ${ }^{4}$

Salah satu pencarian antibiotik yang saat ini banyak dikembangkan adalah dengan memanfaatkan mikroba endosimbion. Mikroba endosimbion merupakan mikroorganisme yang tumbuh dalam jaringan hewan tanpa menunjukkan penyakit pada inangnya.5 Endosimbion juga dapat mensuplai kebutuhan inanngnya. ${ }^{6,7,8}$ Menurut Ishikawa (1989), di samping peranannya dalam mensuplai nutrisi, endosimbion juga mempunyai peran yang bersifat genomic seperti halnya mitokondria atau kloroplas. ${ }^{8}$

Kumar et al., (2011) menyatakan senyawa yang terdapat pada bintang laut Protoreaster lincki dan Pentaceraster regulus memiliki aktivitas antibakteri dan antifungal. Hal ini ditandai adanya zona hambat yang dihasilkan oleh ekstrak bintang laut Protoreaster lincki dan Pentaceraster regulus terhadap bakteri Staphylococcus aureus, Bacillus subtilis, Pseudomonas auroginosa, dan Eschericiacoli. ${ }^{9}$ Bintang laut 
Jamur endosiombion si bintang laut (Asterias forbesi) sebagai alternatif antibakteri baru pada bakteri penyebab infeksi saluran pencernaan

Protoreasterlincki

dan

Pentacerasterregulus juga memiliki zona hambat terhadap khamir Candida albicans dan C. tropicalis.

Hal inilah yang mendasari perlunya dilakukan penelitian mengenai penelusuran dan pengujian aktivitas antimikroba pada mikroba endosimbion pada bintang laut (Asterias forbesi)sebagai pembasmi bakteri patogen khususnya infeksi saluran pencernaan.

\section{METODE PENELITIAN}

Tempat/lokasi dan Waktu

Penelitian

Penelitian ini dilakukan pada bulan Desember 2014 sampai Februari 2015. Dilaksanakan di Laboratorium Mikrobiologi Fakultas Farmasi Universitas Muslim Indonesia.

\section{Populasi dan Sampel Penelitian}

Populasi dalam penelitian adalah bintang laut (Asterias forbesi) dan bakteri uji koleksi Laboratorium Mikrobiologi Farmasi FF-UMI. Sampel yang digunakan adalah jamur endosimbion pada bintang laut (Asterias forbesi) yang berasal dari Kabupaten Takalar dan stok mikroba uji Eschericia coli ATCC 25922, Salmonella thypi NCTC 786, Shigella dysentriae, Staphylococcus aerus ATCC 25923, dan Vibrio cholerea.
Alat dan Bahan yang digunakan

Alat yang digunakan adalah autoklaf (Smic model YX-280 B), botol eluen, cawan petri (Iwaki Pyrex), corong pisah, drigalsky, inkubator (Memmert), Laminar Air Flow (LAF), lampu spiritus, mikroskop, oven (Fisher), penotol, rotavapor, shaker, ose bulat, pipet volume, spoit $(1 \mathrm{~mL}, 5$ $\mathrm{mL}, \quad 10 \mathrm{~mL}), \quad$ swab, vial, spektrofotometri UV-Vis (Genesis) dan timbangan analitik.

Bahan yang digunakan yaitu air suling, agar, bintang laut (Asterias forbesi ), kloramphenikol, isolat bakteri Eschericia coli ATCC 25922, Salmonella thypi NCTC 786, Shigella dysentriae, Staphylococcus aerus ATCC 25923, dan Vibrio cholerea.

\section{Prosedur kerja}

\section{Penyiapan mikroba uji}

\section{Pembuatan suspensi bakteri uji}

Bakteri hasil peremajaan masing-masing disuspensikan dengan larutan $\mathrm{NaCl}$ fisiologis 0,9\% steril, kemudian diukur serapan suspensi biakan dengan spektrofotometer pada panjang gelombang $580 \mathrm{~nm}$ dengan transmisi $25 \%$ T dan sebagai blanko digunakan $\mathrm{NaCl}$ fisiologis 0,9\% steril.

Isolasi bakteri endosimbion pada bintang laut (Asterias forbesi)

Sampel bintang laut (Asterias forbesi) dibersihkan dari kotoran- 
Jamur endosiombion si bintang laut (Asterias forbesi) sebagai alternatif antibakteri baru pada bakteri penyebab infeksi saluran pencernaan

kotoran yang melekat dan dipotongpotong kecil, kemudian dimasukkan ke dalam cawan petri yang berisisi 9 $\mathrm{mL}$ medium Potato Dekstrosa Agar (PDA), yang memadat. Kemudian diinkubasi pada inkubator pada suhu $37^{\circ} \mathrm{C}$ selama $3 \times 24$ jam. Diamati koloni yang memberikan aktivitas membasmi pertumbuhan koloni mikroba lainnya.

Pemurnian isolat jamur endosimbion pada bintang laut (Asterias forbesi).

Setiap isolat yang berbeda dimurnikan dengan metode kuadran untuk memperoleh isolat yang tunggal. Biakan murni tersebut lalu dipindahkan pada agar miring sebagai stok.

\section{Fermentasi biakan murni}

Diambil biakan murni yang telah diinkubasi selama $1 \times 24$ jam dan

\section{HASIL PENELITIAN}

Tabel 1. Hasil pengujian aktivitas antibakteri terhadap bakteri Shigella disentri

\begin{tabular}{ccccccc}
\hline & & \multicolumn{5}{c}{ Diameter Zona Hambat (mm) } \\
\cline { 3 - 6 } No & Konsentrasi ekstrak & r1 & r2 & r3 & Jumlah & Rata-rata \\
\hline 1. & IJBL FF-UMI 01 & 14,0 & 14,0 & 14,0 & 42,0 & 14,0 \\
2. & IJBL FF-UMI 02 & - & - & - & - & - \\
3. & IJBL FF-UMI 03 & - & - & - & - & - \\
4. & IJBL FF-UMI 04 & 14,0 & 15,0 & 15,0 & 44,0 & 14,6 \\
5. & IJBL FF-UMI 05 & 11,0 & 11,0 & 11,0 & 33,0 & 11,0 \\
\hline
\end{tabular}


Uji daya hambat ekstrak etil asetat daun binahong (Anredera coliforlia (Ten.) Steenis) terhadap pertumbuhan bakteri Staphylococcus aureus dan Escherichia coli.

Tabel 2. Hasil pengujian aktivitas antibakteri terhadap bakteri Vibrio cholerea

\begin{tabular}{ccccccc}
\hline \multirow{2}{*}{ No } & \multirow{2}{*}{ Konsentrasi ekstrak } & \multicolumn{5}{c}{ Diameter Zona Hambat (mm) } \\
\cline { 3 - 7 } & r1 & r2 & r3 & Jumlah & Rata-rata \\
\hline 1. & IJBL FF-UMI 01 & 14,0 & 14,0 & 13,0 & 41,0 & 13,6 \\
2. & IJBL FF-UMI 02 & - & - & - & - & - \\
3. & IJBL FF-UMI 03 & - & - & - & - & - \\
4. & IJBL FF-UMI 04 & 16,0 & 18,0 & 17,0 & 51,0 & 17,0 \\
5. & IJBL FF-UMI 05 & 10,0 & 10,0 & 9,0 & 29,0 & 9,6 \\
\hline
\end{tabular}

Tabel 3. Hasil pengujian aktivitas antibakteri terhadap bakteri Staphylococcus aerus

\begin{tabular}{ccccccc}
\hline \multirow{2}{*}{ No } & \multirow{2}{*}{ Konsentrasi ekstrak } & \multicolumn{5}{c}{ Diameter Zona Hambat (mm) } \\
\cline { 3 - 7 } & r1 & r2 & r3 & Jumlah & Rata-rata \\
\hline 1. & IJBL FF-UMI 01 & 15,0 & 16,0 & 14,0 & 45,0 & 15,0 \\
2. & IJBL FF-UMI 02 & - & - & - & - & - \\
3. & IJBL FF-UMI 03 & - & - & - & - & - \\
4. & IJBL FF-UMI 04 & 14,0 & 13,0 & 14,0 & 41,0 & 13,6 \\
5. & IJBL FF-UMI 05 & 10,0 & 10,0 & 9,0 & 29,0 & 9,6 \\
\hline
\end{tabular}

Tabel 4. Hasil pengujian aktivitas antibakteri terhadap bakteri Salmonella thypi

\begin{tabular}{ccccccc}
\hline \multirow{2}{*}{ No } & \multirow{2}{*}{ Konsentrasi ekstrak } & \multicolumn{5}{c}{ Diameter Zona Hambat (mm) } \\
\cline { 3 - 7 } & & $\mathbf{r 1}$ & r2 & r3 & Jumlah & Rata-rata \\
\hline 1. & IJBL FF-UMI 01 & 14,0 & 13,0 & 13,0 & 40,0 & 13,3 \\
2. & IJBL FF-UMI 02 & 11,0 & 10,0 & 11,0 & 32,0 & 10,6 \\
3. & IJBL FF-UMI 03 & 22,0 & 21,0 & 21,0 & 64,0 & 21,3 \\
4. & IJBL FF-UMI 04 & 15,0 & 14,0 & 14,0 & 43,0 & 14,3 \\
5. & IJBL FF-UMI 05 & 13,0 & 13,0 & 14,0 & 40,0 & 13,3 \\
\hline
\end{tabular}

Tabel 5. Hasil pengujian aktivitas antibakteri terhadap bakteri Eschericia coli

\begin{tabular}{ccccccc}
\hline \multirow{2}{*}{ No } & Hasil isolat bintang laut & \multicolumn{5}{c}{ Diameter Zona Hambat (mm) } \\
\cline { 3 - 7 } & (Asterias forbesi) & r1 & r2 & r3 & Jumlah & Rata-rata \\
\hline 1. & IJBL FF-UMI 01 & 14,0 & 14,0 & 13,0 & 41,0 & 13,6 \\
2. & IJBL FF-UMI 02 & - & - & - & - & - \\
3. & IJBL FF-UMI 03 & - & - & - & - & - \\
4. & IJBL FF-UMI 04 & 16,0 & 16,0 & 15,0 & 47,0 & 15,6 \\
5. & IJBL FF-UMI 05 & 10,0 & 9,0 & 9,0 & 28,0 & 9,3 \\
\hline
\end{tabular}


Uji daya hambat ekstrak etil asetat daun binahong (Anredera coliforlia (Ten.) Steenis) terhadap pertumbuhan bakteri Staphylococcus aureus dan Escherichia coli.
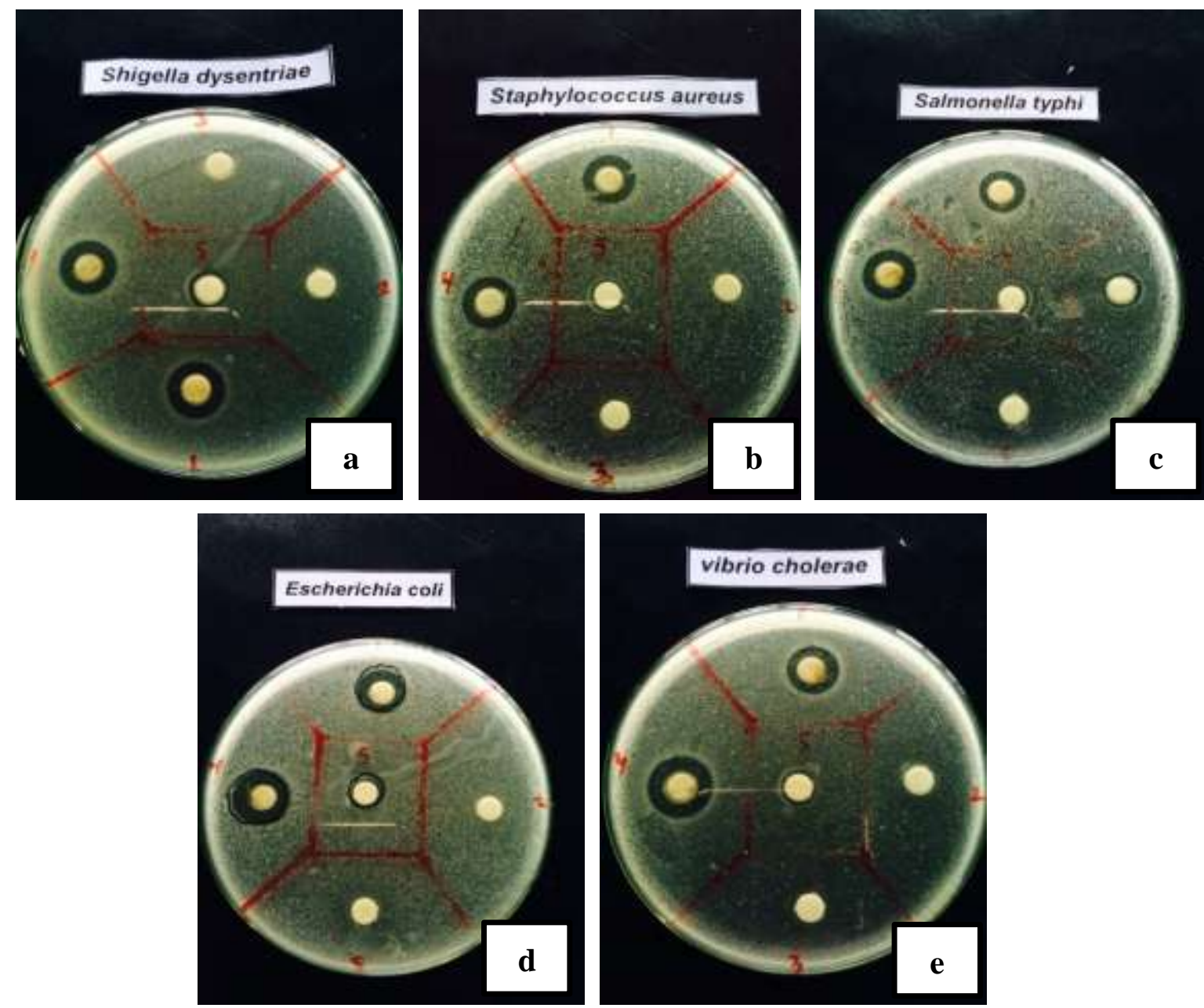

Gambar 1. Foto hasil pengujian aktivitas antibakteri terhadap bakteri uji yaitu (a) Shigella disentri, (b) Staphylococcus aureus, (c) Salmonella typhi, (d) Escherichia coli dan (e) Vibrio cholera.

\section{PEMBAHASAN}

Bintang laut (Asterias forbesi) merupakan salah satu hewan yang berpotensi sebagai obat. Telah dilakukan penelitian sebelumnya yaitu Kumar et al., (2011) menyatakan senyawa yang terdapat pada bintang laut Protoreaster lincki dan Pentaceraster regulus memiliki aktivitas antibakteri dan antifungal. Secara empiris hewan ini dipercaya mampu menyembuhkan penyakit asma dan artritis rematoid. ${ }^{9}$ Pencarian sumber senyawa bioaktif terus menerus dilakukan seiring dengan makin banyaknya penyakit-penyakit baru yang bermunculan, mulai dari penyakit infeksi, kanker dan beberapa penyakit berbahaya lainnya. Salah satu pencarian antibiotik yang saat ini banyak dikembangkan adalah dengan memanfaatkan mikroba endosimbion. 
Uji daya hambat ekstrak etil asetat daun binahong (Anredera coliforlia (Ten.) Steenis) terhadap pertumbuhan bakteri Staphylococcus aureus dan Escherichia coli.

Adapun dasar pemilihan bakteri uji yang digunakan karena didasarkan pada sifat-sifat patogeniknya. ${ }^{10,11}$ Eschericia coli dan Salmonella thypi merupakan bakteri anaerob fakultatif, Gram negatif yang bersifat patogenik penyebab utama diare kronik, demam tifoid dan infeksi saluran kemih. Shigella dysenteriae merupakan penyebab penyakit disentri. Staphylococcus aureus merupakan bakteri kokus Gram positif yang bersifat patogenik penyebab infeksi kulit dan makanan. Vibrio cholerea merupakan bakteri bentuk koma, aerob dan menghasilkan endotoksin, penyebab kolera.

Dari hasil isolasi bintang laut (Asterias forbesi) diperoleh sebanyak lima isolat, proses selanjutnya dimurnikan dengan cara digores pada media NA (Nutrien Agar) hingga didapat koloni murni yang terpisah. Isolat yang diperoleh dari proses fermentasi dipilih dilanjutkan ke tahap produksi, dengan tujuan untuk memperbanyak fermentat yang diperoleh untuk dilanjutkan ke pengujian selanjutnya. Dalam proses produksi senyawa antibiotika dilakukan fermentasi dengan menggunakan medium MYB (Maltosa Yeast Broth). Kemudian dilakukan proses fermentasi digunakan shaker dengan kecepatan 200 rpm selama 14x 24 jam. Hasil pengujian efektivitas antibakteri dengan metode difusi agar, memberikan efektivitas terhadap semua isolat bakteri uji berdasarkan zona hambatan yaitu zona bening disekitar disk.

Untuk semua isolat aktif dihambat oleh isolat jamur endosimbion dengan diameter zona hambatan pada setiap mikroba uji yaitu Shigella dysentriae pada isolat IJBL FF-UMI 01 yaitu sebesar 14,0 $\mathrm{mm}$, isolat IJBL FF-UMI 04 yaitu sebesar 14,6 mm, isolat IJBL FF-UMI 05 yaitu sebesar 11,6 mm. Pada mikroba uji Vibrio cholerea pada isolat IJBL FF-UMI 01 yaitu sebesar 13,6 $\mathrm{mm}$, isolat IJBL FF-UMI 04 yaitu sebesar $17,0 \mathrm{~mm}$, isolat IJBL FF-UMI 05 yaitu sebesar 9,6 mm. Pada mikroba uji Staphylococcus aerus pada isolat IJBL FF-UMI 01 yaitu sebesar $15,0 \mathrm{~mm}$, isolat IJBL FF-UMI 04 yaitu sebesar $13,0 \mathrm{~mm}$, isolat endosimbion IJBL FF-UMI 05 yaitu sebesar 9,6 mm.. Pada mikroba uji Salmonella thypi pada isolat IJBL FFUMI 01 yaitu sebesar 13,3 mm, IJBL FF-UMI 02 yaitu sebesar 10,6 mm, isolat IJBL FF-UMI 03 yaitu sebesar $21,3 \mathrm{~mm}$, isolat IJBL FF-UMI 04 yaitu sebesar 14,3 mm, dan isolat IJBL FFUMI 05 yaitu sebesar 13,3 mm.. dan 
Uji daya hambat ekstrak etil asetat daun binahong (Anredera coliforlia (Ten.) Steenis) terhadap pertumbuhan bakteri Staphylococcus aureus dan Escherichia coli.

Eschericia coli pada isolat IJBL FFUMI 01 yaitu sebesar 13,6 mm, IJBL FF-UMI 04 yaitu sebesar 15,6 mm, isolat IJBL FF-UMI 05 yaitu sebesar 9,3 mm.

Bakteri uji Shigella dysentriae paling aktif dihambat pada isolat IJBL FF-UMI 04 dengan diameter zona hambatan 14,6 mm, kemudian pada isolat IJBL FF-UMI 01 dengan diameter zona hambatan $14,0 \mathrm{~mm}$ dan pada isolat IJBL FF-UMI 05 dengan diameter zona hambatan $11,0 \mathrm{~mm}$.

Bakteri uji uji Vibrio cholerea paling aktif dihambat pada isolat IJBL FF-UMI 04 dengan diameter zona hambatan 17,0 mm, kemudian pada isolat IJBL FF-UMI 01 dengan diameter zona hambatan 13,6 mm dan pada isolat IJBL FF-UMI 05 dengan diameter zona hambatan 9,6 mm.

\section{Bakteri uji Staphylococcus} aerus paling aktif dihambat pada isolat jamur endosimbion IJBL FF-UMI 01 dengan diameter zona hambatan 15,0 $\mathrm{mm}$, kemudian pada isolat IJBL FFUMI 04 dengan diameter zona hambatan 13,6 $\mathrm{mm}$ dan pada isolat IJBL FF-UMI 05 dengan diameter zona hambatan 9,6 $\mathrm{mm}$.

Bakteri uji Salmonella thypi paling aktif dihambat pada isolat IJBL FF-UMI 03 dengan diameter zona hambatan $21,3 \mathrm{~mm}$, kemudian pada isolat IJBL FF-UMI 04 dengan diameter zona hambatan 14,3 mm, kemudian pada isolat IJBL FF-UMI 01 dan 5 dengan diameter zona hambatan $13,3 \mathrm{~mm}$, dan pada isolat jamur endosimbion 2 dengan diameter zona hambatan 10,3 mm.

Bakteri uji Eschericia coli paling aktif dihambat pada isolat IJBL FF-UMI 04 dengan diameter zona hambatan $15,6 \mathrm{~mm}$, kemudian pada isolat jamur endosimbion IJBL FF-UMI 01 dengan diameter zona hambatan $13,6 \mathrm{~mm}$ dan pada isolat IJBL FF-UMI 05 dengan diameter zona hambatan 9,3 $\mathrm{mm}$.

Dari data yang didapatkan menunjukkan bahwa bakteri uji Eschericia coli, Salmonella thypi, Shigella dysentriae, Staphylococcus aerus, Salmonella thypi, dan Vibrio cholerea aktif dihambat oleh isolat jamur endosimbion bintang laut (Asterias forbesi)

\section{KESIMPULAN}

Berdasarkan hasil yang diperoleh dari penelitian yang telah dilakukan maka dapat disimpulkan bahwa Isolat jamur endosimbion pada bintang laut ( Asterias forbesi) dengan kode isolat IJBL FF-UMI 01, IJBL FFUMI 04 dan IJBL FF-UMI 05 efektif memberikan aktivitas anibakteri. Bakteri patogen yang dihambat oleh isolat jamur endosimbion pada 
Uji daya hambat ekstrak etil asetat daun binahong (Anredera coliforlia (Ten.) Steenis) terhadap pertumbuhan bakteri Staphylococcus aureus dan Escherichia coli.

bintang laut (Asterias forbesi) adalah

Eschericia coli, Salmonella thypi, Shigella dysentriae, Staphylococcus aerus, Salmonella thypi, dan Vibrio cholerea.

\section{DAFTAR PUSTAKA}

1. Anam, Khoirul. Implementasi Cooperatif Learning dan Model Pembelajaran dalam Pembelajaran Geografi, Adaptasi Model Jigsaw dan Field Study.. Badan Penalitian dan Pengembangan Departemen Pendidikan. Jurnal IImu Pendidikan, 2009.

2. Gillespie SH and Bamfoard KB. At a Glance Mikrobiologi Medis dan Infeksi, Edisi 3. Jakarta : Erlangga, 2009.

3. Kandhasamy $M$, Arunachalam, Thatheyus AJ. Drynaria quercifolia (L.) J.Sm: A potential resource for antibacterial activity. African Journal of Microbiology Research, 2008:2.

4. Prihatiningtias W. Senyawa Bioaktif Fungi Endofit Akar Kuning (Fibraurea chloroleuca Miers) Sebagai Senyawa Antimikroba (Tesis). Jogjakarta : Sekolah Pascasarjana UGM, 2005.
5. Stansfield W, R Cano, J. Colome. Molecular and cell biologi. McGraw-Hill, New York, 2003.

6. Koch A. Intacellular symbiosis in insect. Annu Rev of Microbiol 1960.

7. Dadd RH. Nutrition : Organism. In Kerkut, G.A. and L.I. Gilbert (Eds.). Comprehensive insect Physiology Biochemistry and Pharmacology. Oxford: Pergamon, 1985.

8. Ishikawa H. Biochemical and molecular aspects of endosymbiosis in insect. Int Rev of Cytol 1989.

9. Kumar et al. Treatment of Paper and Pulp Mill Effluent by Coagulation. International Journal of Civil and Environmental Engineering 2011;3(3).

10. Jawetz E, Melnick JL, Adelbreg's EA. Mikrobiologi Kedokteran (Medical Microbiologi)., Terjemahan Edi Nugroho dan R.F. Maulani. Jakarta : Penerbit buku kedokteran EGC, 1991.

11. Sinaga E, Noverita, Dinah Fitria. Daya Antibakteri Jamur Endofit Yang Diisolasi dari Daun dan Rimpang Lengkuas (Alpinia galangal Sw.). Dipublikasikan dalam Jakarta : Jurnal Farmasi Indonesia, 2009. 